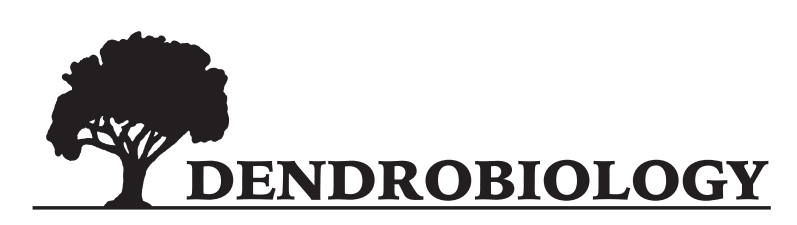

2015, vol. 74, 157-168

http://dx.doi.org/10.12657/denbio.074.016

Lina Straigytè, Gunta Cekstere, Maris Laivins, Vitas Marozas

\title{
The spread, intensity and invasiveness of the Acer negundo in Riga and Kaunas
}

Received: 6 February 2015; Accepted: 17 June 2015

\begin{abstract}
Ashleaf Maple (Acer negundo L.) was first introduced in Latvia and Lithuania at the beginning of the $19^{\text {th }}$ century. It is the most widely distributed alien maple species to be found in the parks and greeneries of Riga and Kaunas. In recent decades, the spread and invasion of this species has been observed. The aim of this research was to determine the extent and effects of the invasiveness A. negundo in Riga and Kaunas. The degree of invasion by this species' was estimated by applying the Pest Plant Prioritization Process, which is based on the Analytic Hierarchy Process method. The results showed that the invasive degree of box elder was very high (0.788); the present compared to potential distribution rating was medium high (0.71) and the social, environmental and economic impact score was low (0.23). The Final Pest Plant Score for $A$. negundo was medium (0.4506). The obtained estimates indicated that box elder was invasive and was able to spread rapidly into new riparian areas.
\end{abstract}

Addiotional key words: Ashleaf maple, spread, invasiveness, Pest Plant Score

Addresses: L. Straigytė, G. Cekstere, M. Laivins, V. Marozas, Institute of Biology of the University of Latvia. Miera street 3, Salaspils, LV-2169, Latvia, e-mail: lina.straigyte@asu.lt

L. Straigyte, V. Marozas, Faculty of Forest Science and Ecology of the Aleksandras Stulginskis University. Studentu 11, LT - 53361 Akademija, Kaunas distr. Lithuania

M. Laivins, LSFRI „Silava“, Rigas street 111, Salaspils, LV-2169, Latvia

\section{Introduction}

Ashleaf Maple (Acer negundo L.) also known Manitoba Maple in Canada, and Box elder in America is native to North America and is the most widely distributed of all American maples. Its native range extends across the U.S. and from Alberta, Canada in the north and to southern Mexico and Guatemala in the south (USDA). In North western America it is found primarily in river canyons where it may form extensive riparian forests (DeWine and Cooper 2007). However, in parts of northern America it can be found outside its natural distribution range and is considered as an alien species (Planty-Tabacchi et all. 1996). Seed crops are produced annually, beginning at 8 to 11 years of age (Schopmeyer 1974). The species is dioeciously and comparing with other urban maple species, has a short life cycle. Open-grown $A$. negundo trees usually have an irregular form, with the main stem dividing near the ground, resulting in a large uneven crown. In Canada, the diameter at breast height of the main stem rarely exceeds $60 \mathrm{~cm}$, and heights in excess of $15 \mathrm{~m}$ are uncommon (Blouin 1992). A. negundo develops deep roots, and stump suckers and prefers to grow in moist soils (Rauktys 1933). It has 
also been known to survive an inundation of water for as long as 30 days (Hosner 1960), and subsequent research indicates that established trees can tolerate being inundated for longer than 85 days (Friedman and Auble 1999). The species was deliberately introduced to different countries in Europe together with a number of other American plant species in the seventeenth century (Mędrzycki 2007; Erfmeier 2011).

Scientific literature provides different opinions about the introduction and cultivation of $A$. negundo in Lithuania. According to Gudžinskas (1998), A. negundo was initially cultivated in the 1930 s and was first recorded as an invasive species in 1963. However, according to Rauktys (1933), A. negundo was grown in Lithuania long before the $20^{\text {th }}$ century. Whilst Skridaila (2001) reported that A. negundo was growing in the Vilnius University botanical garden in 1804. As a fast-growing and winter-hardy species, it was frequently planted as an ornamental tree in both cities and farmyards (Rauktys 1933). Kowarik (1995) state's that after introduction, the naturalization of many trees takes approximately 170 years, until they began to spread. In agreement, after 150 years since its introduction, $A$. negundo was reported to be growing and bearing fruit in Lithuania (Janušauskaitė 1935; Ramanauskas 1973). In general, between 1928-1939, A. negundo was abundantly grown in nurseries for ornamental gardening in Lithuania. After the Second World War, it was planted in forests, however after 1960 was deemed not suitable for forestry and as a result was no longer propagated in nurseries (Kairiūkštis 1968). Subsequent descriptions mention that in Lithuania, these maples are frequently found growing near homesteads, in urban landscapes, parks, nurseries, protective plantations, along roadsides and railways (Navasaitis 1979; 2004). They have also been used for forest land reclamation - on slopes, and in more humid sandy soils. In industrial centres, they have been assessed as being fume and dust resistant, and can be used quickly to repopulate vacant areas. Further planting is not recommended for urban areas, because it is already widespread (LTSR Flora 1971). Officially in Lithuania $A$. negundo was considered an invasive alien tree species in 2004 (Anonymous 2004) and in 2013-2015 the Lithuanian Ministry of Environmental organized the ongoing project "Regulatory measures of invasive plant species abundance".

In Latvia, A. negundo was first introduced in tree nurseries at the beginning of the $19^{\text {th }}$ century (Zigra 1817; Wagner 1822) and was also used as an element of urban greenery in Riga. Some decades later, at the end of the $19^{\text {th }}$ century, it became a popular woody species within the vicinity of Riga (Klinge 1883). In the middle of the 20th century, A. negundo was the second most widespread alien maple species behind the Sycamore (Acer pseudoplatanus) (Zarinšs 1959), but only after 20 years, it was deemed the most distributed alien maple species in parks and greeneries in Latvia (Cinovskis et al. 1974). Nowadays, it is considered as a fully naturalized species in Latvia (Gudžinskas 1998; Gavrilova and Šulcs 1999). A. negundo forms up to several square meters large stands in non-used grasslands and ruderal areas in Riga and other urban and rural areas in Latvia.

It should be noted that not all alien plants become invasive. Williamson and Fitter (1996) estimated that approximately $10 \%$ of naturalized plant species become invasive and cause significant economic and ecological impacts. The mass spread of some introduced species has occurred only during the last few decades. In the 1980s-1990s only sporadic findings of $A$. negundo were recorded, but at the beginning of the 2000s, mass spread into vegetative communities of the Volga basin region was observed (Borisova 2011). To make informed decisions about the optimal method of weed control in urban areas, it is necessary that the relative importance of each weed be determined.

The research aim is to determine the relative importance of Acer negundo invasiveness in Riga and Kaunas. The invasiveness can be determined by considering: (a) how invasive they are, how fast can they spread? (b) The present and potential extent of the species; (c) what social, environmental and economic impacts does the species have?

\section{Material and Methods}

Growth and seedling distribution of $A$. negundo in Riga ( $\left.56^{\circ} 57^{\prime} 05^{\prime \prime} \mathrm{N}, 24^{\circ} 06^{\prime} 10^{\prime \prime} \mathrm{E}\right)$, the capital of Latvia, and Kaunas ( $54^{\circ} 53^{\prime} 50^{\prime \prime}$ N, $23^{\circ} 53^{\prime} 10^{\prime \prime}$ E), the second largest city of Lithuania, were analysed. The climate in Riga is moderately warm and humid: the average annual precipitation is about $700 \mathrm{~mm}$, the average temperature in January is $-3.5^{\circ} \mathrm{C}$, and in July $+17.2^{\circ} \mathrm{C}$. The climate in Kaunas is more continental. The average annual precipitation is $550-600 \mathrm{~mm}$, the average temperature in January is $-5.2^{\circ} \mathrm{C}$, and in July $+16.9^{\circ} \mathrm{C}$ (Statistical department data of 2005-2010).

\section{Methods to calculate pest plant score}

The species that are of highest risk are those that have the greatest potential to affect valuable resources. The information that is needed to enable threats to be assessed under this process includes: information about the biology of each species and its potential rate of spread; the species that could threaten the region either now or in the future; the level of impact that a species could have on social, agricultural and environmental resources; the values that land managers assign to affected resources. 


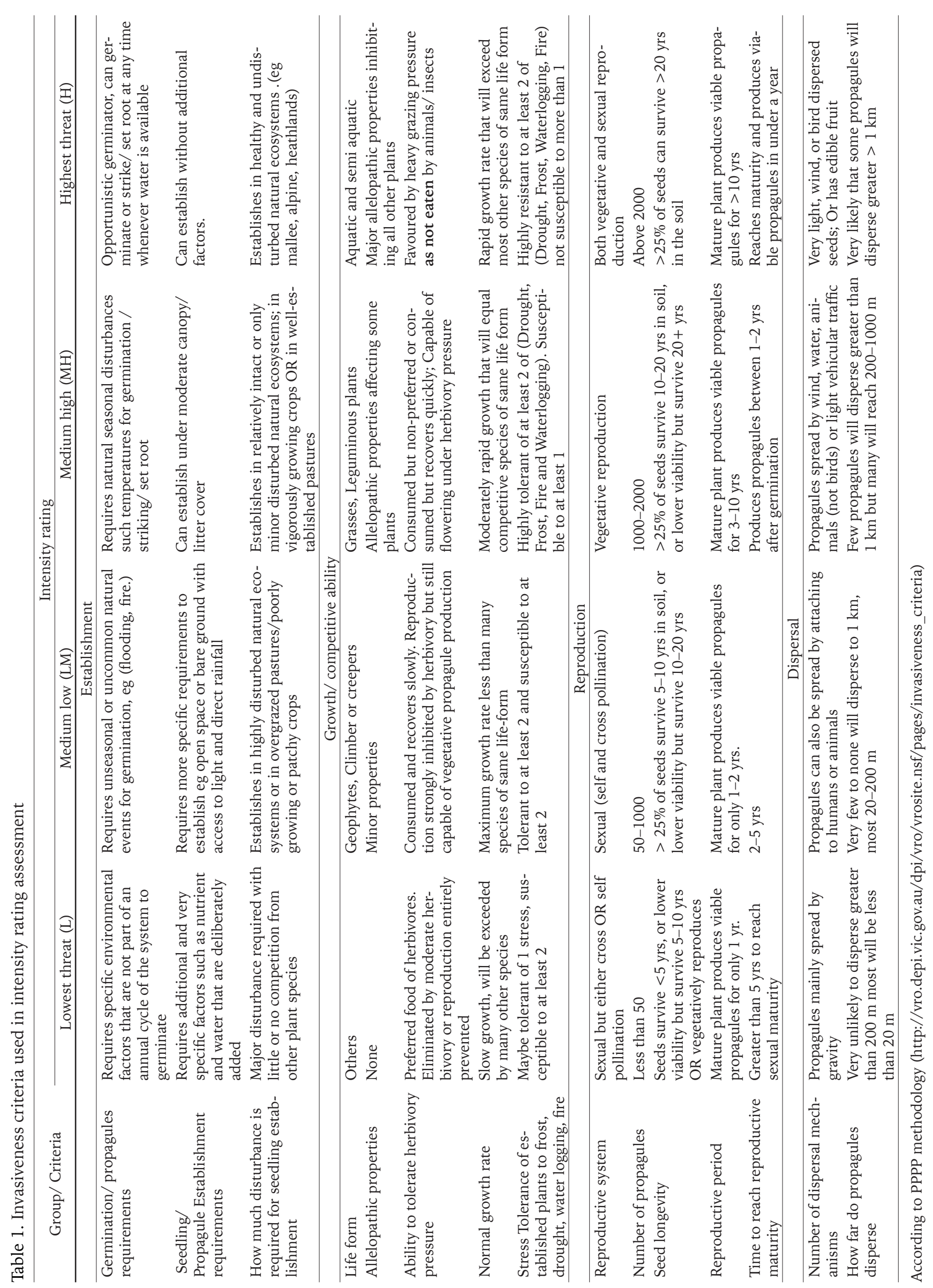


Table 2. Impact score criteria and weight for evaluating influence of the plant

\begin{tabular}{|c|c|}
\hline Criteria & Weight \\
\hline \multicolumn{2}{|l|}{ Social (Tourism, Visual aesthetics, Experience, Cultural sites) } \\
\hline 1. To what extent does the weed restrict human access? & 0.025988 \\
\hline 2. To what level does this weed reduce the 'tourism / aesthetics/ recreational use of the land? & 0.047162 \\
\hline 3. To what level is the plant injurious, toxic, or spines affect people? & 0.01435 \\
\hline 4. How much damage is done to indigenous or european cultural sites? & 0.0125 \\
\hline \multicolumn{2}{|l|}{ Natural resources - soil, water \& processes } \\
\hline 5. To what extent does this weed impact on water flow within watercourses? & 0.041625 \\
\hline 6. To what extent does the weed impact on water quality (ie. Dissolved 02, water temperature)? & 0.083375 \\
\hline 7. To what extent does the weed increase soil erosion? & 0.075 \\
\hline 8. To what extent does this weed reduce the biomass of the community? (nb. Biomass acting as a carbon sink) & 0.005 \\
\hline 9. To what extent does the weed change the frequency or intensity of fires? & 0.045 \\
\hline \multicolumn{2}{|l|}{ Fauna and flora / vegetation \& EVCs } \\
\hline \multicolumn{2}{|l|}{ 10. To what extent does this weed impact on the vegetation composition on the following: } \\
\hline a. High value EVCs & 0.081991 \\
\hline b. Medium value EVCs & 0.049780 \\
\hline c. Low value EVCs & 0.014641 \\
\hline 11. To what extent does this weed effect the structure of a vegetation community? & 0.069062 \\
\hline 12. What effect does the weed have on threatened flora spp.? & 0.060775 \\
\hline 13. What effect does the weed have on threatened fauna spp.? & 0.05474 \\
\hline 14. What effect does the weed have on nonthreatened fauna spp.? & 0.026329 \\
\hline 15. To what extent does this weed provide benefits or facilitates the establishment of indigenous fauna? & 0.023056 \\
\hline 16. To what extent is the plant toxic, its burrs or spines affect fauna? & 0.01666 \\
\hline \multicolumn{2}{|l|}{ Flora and fauna/ fauna /pest animal } \\
\hline 17. To what extent does this weed provide a food source to assist in success of pest animals? & 0.011186 \\
\hline 18. To what extent does this weed provide habitat / harbor for serious pests? & 0.016779 \\
\hline \multicolumn{2}{|l|}{ Agriculture - quality, quantity, cost to production, effect on land value } \\
\hline 19. To what extent does this weed impact on the yield of agricultural produce? & 0.0189 \\
\hline 20. To what extent does the weed impact on agricultural quality? & 0.0324 \\
\hline 21. To what extent does this weed affect land value? & 0.054675 \\
\hline 22. To what extent does this weed cause a change in priority of land use? & 0.1008 \\
\hline 23. To what extent the presence of the weed increases the cost of harvest? & 0.011925 \\
\hline 24. To what extent does this weed act as an alternative host for diseases? & 0.0063 \\
\hline
\end{tabular}

The Pest Plant Prioritisation Process (PPPP) is a prioritization process or risk assessment, based on the Analytic Hierarchy Process (AHP) (Saaty 1995; Weiss and McLaren 2002) that ranks weeds by: assessing the plant invasiveness; comparing the present and potential distribution of plants; assessment of plant impact on social, economic, and environmental values. The PPPP is therefore expressed as a hierarchy, the components of which are weighted (using AHP) to allow the determination of a Pest Plant Assessment score for individual species. Experts determined a preliminary ranking of the three subcomponents of the PPPP (Weiss and McLaren 2002). The basis of the weighting was that invasiveness was considered less important than distribution, which in turn was considered less important than impact. The Pest Plant Assessment score is expressed as: PPS $=\alpha$ (Invasiveness score) $+\beta$ (Present:Potential Distribution) $+\gamma$ (Impact), where $\alpha$ (0.12), $\beta$ (0.32), $\gamma$ $(0.56)$ are weightings of the subcomponents (Weiss and McLaren 2002).
The scored intensity ratings for each criterion and their weightings where calculated to produce a final invasiveness score (eqn. 1):

Invasiveness score $=\Sigma(($ Group weighting $\times$

$\times$ Criterion weighting) $\times$ Intensity rating)

Criteria weights were rated by experts, valuation fixed. Assessment of plant invasiveness was done by evaluating biological and ecological characteristics such as germination requirements, growth rate, competitive ability, reproduction ways and dispersal mechanisms. Intensity rating for every group is defined by assessment of species characteristics (Table 1 ). Assessments have been done by literature analysis, observation of urban greenery and riparian zones in Riga and Kaunas, where Acer negundo grows and spreads.

Present distribution was determined based on the results of inventory data of urban parks in Riga (Pūka et al. 1988) and field assessments during summer 2014, as well as inventory data collected on woody plants in the green areas of Kaunas in 2011-2014. 
The ratio of present to potential distribution provides an indication as to the stage that the spread of alien tree species has reached.

Assessment of plant impacts was determined by the extent to which a species affects environmental, economic and social resources. Species influence was evaluated according to 24 criteria (Table 2), rating them by intensity differences (Weiss and McLaren 2002), based on the following formula (eqn. 2):

$$
\text { Impact Score }=\Sigma(\text { Rating } \times \text { Weight })
$$

Assessments were based on literature analysis, field observations in Riga and Kaunas, as well consultations with ecologists, biologists and foresters.

The final stage of PPPP is to apply the results of invasiveness, distribution and impact assessments to determine the relative importance of weeds by calculating a Pest Plant Score. The formula (eqn. 3) for calculating the Pest Plant Score is:

$$
\begin{gathered}
\text { Pest Plant Score }=\alpha \text { (Invasiveness score })+\beta(\mathrm{P} / \mathrm{P} \\
\text { Distribution })+\gamma(\text { Impact })
\end{gathered}
$$

To assess plants for invasiveness and impact, information from our and other research results were used. Where some information was missing, likely responses were estimated.

\section{Results and discussion}

\section{Invasiveness score of Acer negundo}

Invasiveness can be defined as the ability to establish, reproduce, and disperse within an ecosystem. Plant propagules arrive at a new site with certain inherent characteristics that previously enabled their successful survival and continued reproduction throughout their evolutionary history (Table 3 ).

The studies reveal that $A$. negundo suffers from polluted urban air, has higher crown defoliation and is less healthy in Kaunas city (Stravinskienè 2010). Because of these properties, this maple is not suitable for urban greening and planting along roads. However, it quickly spreads and is healthy in riparian zones. The spread of $A$. negundo on the banks of the Kaunas Reservoir were observed at low $(<1.5$ m) bank heights (Žalkauskas 2000). Seedlings can establish and grow in shaded environments (Wilson 1970).

In its native region, establishment of box elder is strongly dependent on high flows and is adversely affected by river regulation that reduces peak flows (DeWine and Cooper 2007). Rivers in Latvia and Lithuania have high peak flows every spring (data according to State Ltd "Latvian Environment, Ge-

\begin{tabular}{|c|c|c|}
\hline Criteria & Comments & Rating* \\
\hline \multicolumn{3}{|c|}{ Establishment } \\
\hline 1. Germination requirements & $\begin{array}{l}\text { Seeds germinate in spring. Seeds show dormancy (Roe 1941; Irving 1968; Olson \& } \\
\text { Gabriel 1974; Cram 1983) }\end{array}$ & $\mathrm{MH}$ \\
\hline 2. Establishment requirements & Occurs in moderate litter, herbal cover. & MH \\
\hline 3. Disturbance requirements & Establishes in riparian zone, abandoned farms, derelict house land & $\mathrm{MH}$ \\
\hline \multicolumn{3}{|c|}{ Growth/competitive ability } \\
\hline 4. Life form & $\begin{array}{l}\text { Low tree form, often have multiple stems, average age of } 60 \text { years, sometimes - } 100 \\
\text { years (Green 1934). }\end{array}$ & $\mathrm{L}$ \\
\hline 5. Allelopathic properties & Roots, leaves made moderate effect (Kolesnichenko and Spakhov 1969) & M \\
\hline 6. Tolerates herbivory pressure & Not eaten by animals & $\mathrm{H}$ \\
\hline 7. Normal growth rate & Shoots rapid growth in the young, increasing 1.5-2 meters. Gap colonising tree & $\mathrm{H}$ \\
\hline 8. Stress tolerances & $\begin{array}{l}\text { Highly resistant of frost, drought, tolerates many soil types, } \mathrm{pH} \text { range } 4.4-7.9 \mathrm{pH} \\
\text { (USDA). Survive inundation for as long as } 30 \text { days (Hosner 1960). But suffer from } \\
\text { polluted urban air (Stravinskienè 2010) }\end{array}$ & $\mathrm{MH}$ \\
\hline \multicolumn{3}{|c|}{ Reproduction } \\
\hline 9. Reproductive system & Reproducing by seeds, after cutting, abundant stump suckers. Monosexual & $\mathrm{MH}$ \\
\hline 10. Propagule production & 70 thousand seeds (Valantinaitė et al. 2011). & $\mathrm{H}$ \\
\hline 11. Seed longevity & $\begin{array}{l}\text { Seed viability maintained for } 1-2 \text { years in hermetic storage at } 2^{\circ} \mathrm{C} \text { to } 5^{\circ} \mathrm{C} \text { with } 10- \\
15 \% \mathrm{mc} \text { (Olson \& Gabriel 1974) }\end{array}$ & $\mathrm{L}$ \\
\hline 12. Reproductive period & $\begin{array}{l}\text { Mature female tree produce new growth each spring, more fertile years is repeated } \\
\text { every few years }\end{array}$ & $\mathrm{H}$ \\
\hline \multirow[t]{2}{*}{ 13. Time to maturity } & Tree does not flower until 8-11 years old (Schopmeyer 1974) & $\mathrm{L}$ \\
\hline & Dispersal & \\
\hline 14. Number of mechanisms & Propagules spread by wind, water. Thousand seed weight is $40 \mathrm{~g}$ to $70 \mathrm{~g}$ & $\mathrm{MH}$ \\
\hline 15. How far do propagules disperse & River could disperse seeds many $\mathrm{km}$ & $\mathrm{H}$ \\
\hline
\end{tabular}
ology and Meteorology Centre"). The water level in

Table 3. Invasiveness rating for Acer negundo, according to criteria

*Rating: $\mathrm{L}$ - lowest threat, $\mathrm{ML}$ - medium low, $\mathrm{M}$ - medium, $\mathrm{MH}$ - medium high, $\mathrm{H}$ - highest threat. 
Table 4. Determination of Invasiveness score in Riga and Kaunas

\begin{tabular}{|c|c|c|c|c|}
\hline Group & Criteria & Rating & Weight* & Impact \\
\hline \multicolumn{5}{|l|}{ Establishment } \\
\hline & Germination requirements? & 0.75 & 0.0425 & 0.0319 \\
\hline & Establishment requirements? & 0.75 & 0.3355 & 0.2516 \\
\hline & Disturbance requirements? & 0.75 & 0.122 & 0.0915 \\
\hline \multicolumn{5}{|c|}{ Growth/competitive ability } \\
\hline & Life form? & 0 & 0.00576 & 0 \\
\hline & Allelopathic properties? & 0.5 & 0.00864 & 0.0043 \\
\hline & Tolerates herbivory pressure? & 1 & 0.0456 & 0.0456 \\
\hline & Normal growth rate? & 1 & 0.018432 & 0.0184 \\
\hline & Stress tolerances? & 0.75 & 0.01776 & 0.01332 \\
\hline \multicolumn{5}{|l|}{ Reproduction } \\
\hline & Reproductive system? & 0.75 & 0.005593 & 0.004195 \\
\hline & Propagule production? & 1 & 0.05474 & 0.05474 \\
\hline & Seed longevity? & 0 & 0.030464 & 0 \\
\hline & Reproductive period? & 1 & 0.012019 & 0.012 \\
\hline & Time to reproductive maturity? & 0 & 0.016184 & 0 \\
\hline \multicolumn{5}{|l|}{ Dispersal } \\
\hline & Number of mechanisms? & 0.75 & 0.094572 & 0.070929 \\
\hline & How far do propagules disperse? & 1 & 0.189428 & 0.1894 \\
\hline & & & & 0.788 \\
\hline
\end{tabular}

* Weight valuation fixed, evaluated by experts.

the Nemunas River fluctuates constantly due to the impact of the Kaunas hydroelectric station. This indicates that in the future, box elder will spread to new riparian zones.

Another factor which affects the spread of box elder in urban territories is wind. It is difficult to clearly distinguish the effect of wind only, as birds and animals also spread seeds. The impact of wind is smaller than that of water, as the furthest detected seedling was 100 meters distant from the parent tree, and water carries seeds for longer distances (Valantinaite et al. 2011). The spread of alien species is assisted not only by water, wind, animal and birds, but also is accelerated by growing trade, tourism and cross-border freight transport. Invasion of Acer species is enhanced by soil biota associated with dominant native species and the soil biota effect becomes more inhibitory as the Acer species becomes established (Reinhart and Callaway 2004). Determination of Invasiveness score is shown in Table 4.

Results show that the invasiveness score of 0.8 for A. negundo is very high.

Invasiveness of woody plant species in disturbed landscapes is associated with small seed mass $(<50$ $\mathrm{mg}$ ), a short juvenile period ( $<10$ years) and short intervals between large seed crops (1-4 years) (Rejmánek and Richardson 1996). A. negundo have all these characteristics; seed mass is small (thousand seed weight is $40 \mathrm{~g}$ to $70 \mathrm{~g}$ ), trees have a short juvenile period (they start to flower at age 8-11), and short intervals between large seed crops. Winged samara enables long distance dispersal of seeds. Long reproductive periods also seem to be associated with invasiveness (Reichard 1994). A. negundo have long reproductive periods, with trees on average living 60 years, with some trees living up to 100 years.

\section{Evaluating the present compared to potential distribution}

Current and potential distributions are another major component required in the decision support system and AHP to predict the status of a weed. All species are more invasive in regions that are climatically similar to their native environment. A.negundo USDA hardiness zones are 2-7. The territory of Riga and Kaunas is located in the $5^{\text {th }}$ to $6^{\text {th }}$ hardiness zones. This means that the winter climate in Riga and Kaunas is very suitable for this species. According to the Riga inventory data, A. negundo is distributed throughout most of the city areas and is recorded in $43 \%$ of the parks (Fig. 1 ).

Fig. 1 present the distribution of all trees, planted as ornamental and unassisted spread. Most of new seedlings grow near the Daugava River in sparsely covered areas, where they have a high potential for spread of propagules. In Kaunas (Fig. 2), a high abundance of $A$. negundo individuals grow in the riparian zones of the Nemunas and Neris rivers. As an ornamental tree, this species has a very frequent occurrence $(58 \%)$ in public parks and squares. During the last years, $A$. negundo has been eradicated in some riparian parks of Kaunas. However, during spring following removal, a new infestation of $A$. negundo propagules was observed, as not all female riparian trees had been eradicated. 


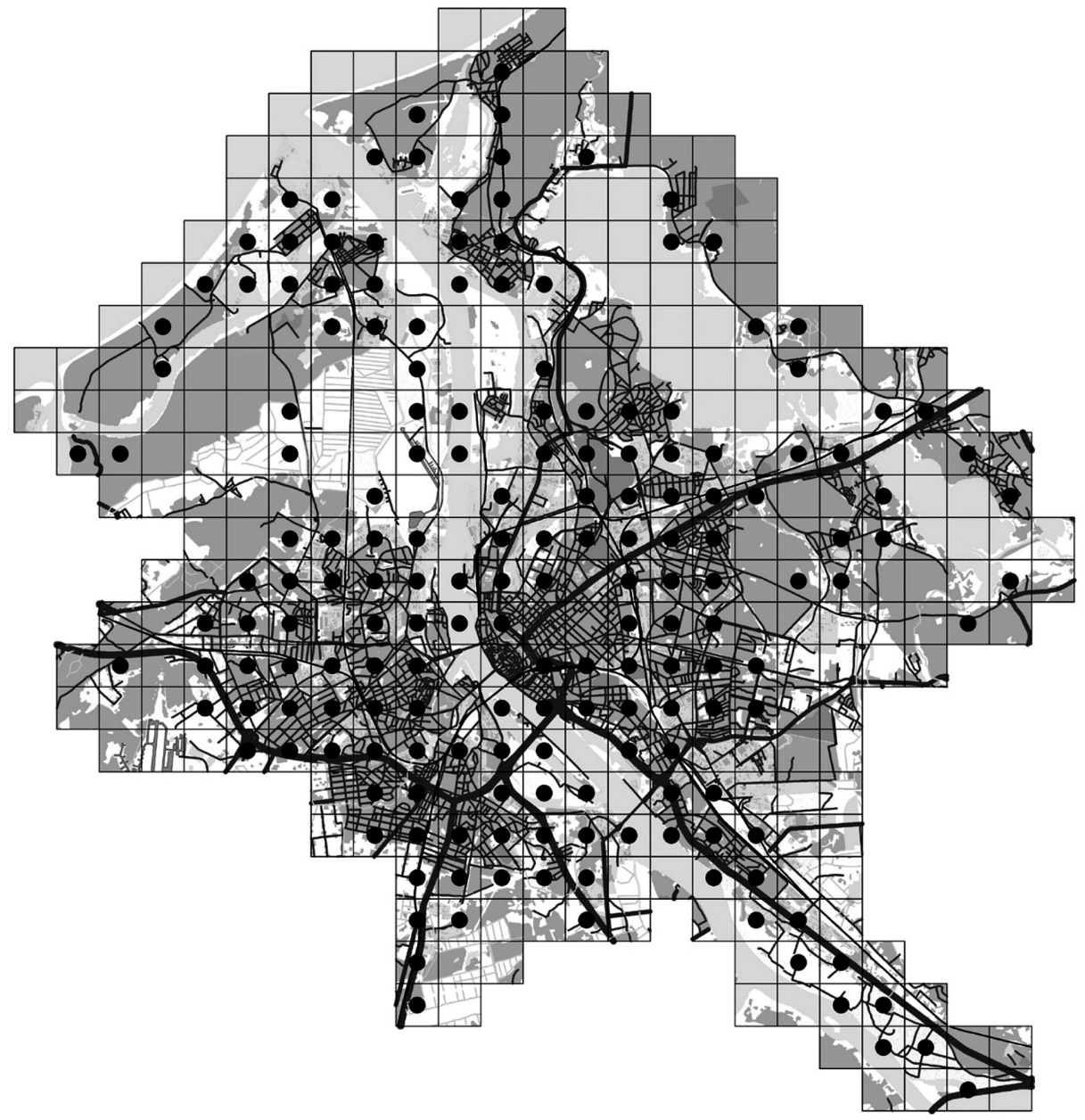

Fig. 1. Present distribution of Acer negundo in Riga (Raster $1 \times 1 \mathrm{~km}$ )

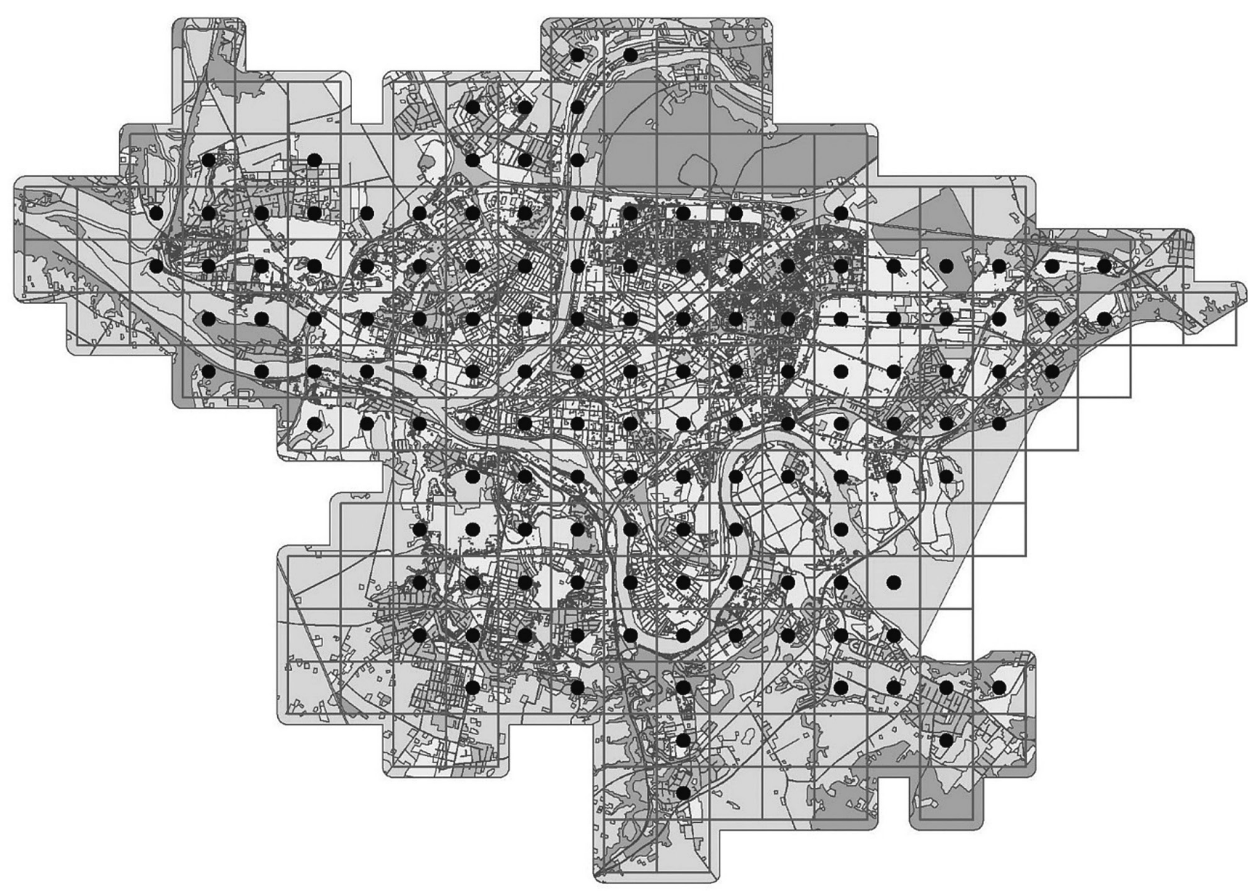

Fig. 2. Present distribution of Acer negundo in Kaunas (Raster $1 \times 1 \mathrm{~km}$ ) 
Table 5. Intensity rating for evaluating the present compared to potential distribution

\begin{tabular}{lcl}
\hline \multicolumn{1}{c}{ Rating } & Weight & \\
\hline Very high & 1 & Infestation(s) that are able to be eradicated with no chance of reinvasion from outside of area of control. \\
High & 0.85 & Infestation(s) that are able to be eradicated with some chance of reinvasion \\
Medium high & 0.71 & Several small infestations beyond eradication \\
Medium & 0.57 & A large partially dispersed infestation or few widely scattered small infestations \\
Medium low & 0.42 & Numerous large dispersed infestations or lots of scattered small infestations. \\
Low & 0.28 & The majority of region infested with some large areas still "clean" (more "clean" areas than infested) \\
Very low & 0.14 & The majority of region infested with some smallish areas still "clean" (less "clean" areas than infested) \\
Extremely low & 0 & Reached full potential - but may increase in density within infested area
\end{tabular}

Potential distribution of $A$. negundo in the both cities could be characterized as medium high with an intensity rating weight 0.71 . A characteristic feature of this species is reinvasion, especially in riparian zones, after cutting. Intensity ratings for evaluating the ratio of present to potential distribution are shown in Table 5.

According Höfle et al. (2014), the probability of occurrence for $A$. negundo was higher in areas with a close proximity to water and in areas which were located in softwood floodplain forests. Kaunas and Riga have areas with these characteristics.
The spread of many alien species is heavily dependent on human activity (Panetta and Scanlan 1995). Newly sprouted $A$. negundo seedlings were found in high abundance in waterside areas of Kaunas, which are influenced by different types of human activity: creating an embankment, dumping of sand dredged from the Nemunas River. These activities facilitate $A$. negundo to replenish its potential distribution. Disturbance increases plant invasions by providing suitable microsites for germination and seedling establishment and by increasing light and nutrient availability that enhance seedling survival and growth (Hobbs and Huenneke 1992). Some riparian weeds may oc-

Table 6. Social, environmental and economic impact rating

\begin{tabular}{|c|c|c|}
\hline Criteria & Comments & Rating \\
\hline 1. Restrict human access? & Would not hinder human access & $\mathrm{L}$ \\
\hline 2. Reduce tourism? & The species is cultivated as ornamental tree in cities & $\mathrm{L}$ \\
\hline 3. Injurious, toxic, or spines affect people? & Not toxic and spines & $\mathrm{L}$ \\
\hline 4. Damage to cultural sites? & Riparian spread of maples create a negative visual impact on cultural sites & LM \\
\hline 5. Impact on water flow? & $\begin{array}{l}\text { Established trees on inundation can stay longer } 85 \text { days (Friedman \& Auble } \\
\text { 1999) }\end{array}$ & M \\
\hline 6. Impact on water? & Can effect on water quality & M \\
\hline 7. Increase soil erosion? & Not increase soil erosion & $\mathrm{L}$ \\
\hline 8. Reduce the biomass of the community? & Biomass of the community may increase on the slopes of the riversides & $\mathrm{L}$ \\
\hline 9. Change fire regime? & Not impact on fire in cities & $\mathrm{L}$ \\
\hline \multicolumn{3}{|l|}{$\begin{array}{l}\text { 10. To what extent does this weed impact on } \\
\text { the vegetation composition on the following: }\end{array}$} \\
\hline a. High value EVCs & $\begin{array}{l}\text { EVC = Floodplain Riparian Woodland. Major displacement of some domi- } \\
\text { nant sp. }\end{array}$ & $\mathrm{MH}$ \\
\hline b. Medium value EVCs & $\begin{array}{l}\text { EVC= Sedgy Riparian Woodland. Gradual displacement of some dominant } \\
\text { sp. }\end{array}$ & M \\
\hline c. Low value EVCs & $\mathrm{EVC}=$ Riparian Scrub Minor displacement of some dominant sp. & ML \\
\hline 11. Impact on vegetation community structure? & Affects all levels - ground cover, shrubs, & M \\
\hline 12. Effect on threatened flora? & Not recorded in the cities flora & $\mathrm{L}$ \\
\hline 13. Effect on threatened fauna? & Effect unsighted & $\mathrm{L}$ \\
\hline 14. Effect on nonthreatened fauna? & Unknown negative effect & $\mathrm{L}$ \\
\hline 15. Benefits fauna? & Provides some food and shelter for birds, mammals & $\mathrm{MH}$ \\
\hline 16. Injurious to fauna? & No effect & $\mathrm{L}$ \\
\hline 17. Food to pest animals? & Provides the minimal food for pest animals. & ML \\
\hline 18. Provide harbour? & Provide harbour for rabbits, foxes & $\mathrm{H}$ \\
\hline 19. Impact yield? & Little impact on quantity of yield. & $\mathrm{L}$ \\
\hline 20. Impact on agricultural quality? & Negligible impact on quality of yield. & $\mathrm{L}$ \\
\hline 21. Affect land value? & Not affect land value & $\mathrm{L}$ \\
\hline 22. Change land use? & No change & $\mathrm{L}$ \\
\hline 23. Increase harvest cost? & Minor increase, if need to cut shoots & ML \\
\hline 24. Disease host? & No host & $\mathrm{L}$ \\
\hline
\end{tabular}


cur along small rivers, streams and water channels. This is a major limitation when predicting their potential distribution. Other non-riparian weeds are recorded as occurring along roadsides and in forest gaps. The present compared to potential distribution of Quercus rubra in Lithuania was evaluated with a medium intensity rating (weight 0.57 ) (Riepšas and Straigyte 2008). The spread of this species is limited by soil fertility and density of grass cover.

\section{Determining the social, environmental and economic impacts}

The next stage of the PPPP, before calculating a Pest Plant Score, is to determine the social, environmental, and economic impacts of pest species. Criteria ratings for determining $A$. negundo impact are show in Table 6.
The highest rating is for the criterion that $A$. negundo provides shelter and benefits for fauna. The influence of this species on soil is unknown, as leaf litter decomposes faster than other leaf litter of other maple species (Janušauskaitė and Straigytė 2011). The influence of $A$. negundo on other plants seems not to differ too much from the impact of other trees.

Our results revealed (Table 7 ) that the impact score is low (0.23).

\section{Pest Plant Score}

The final stage of the PPPP is to apply the results of invasiveness (Table 4), distribution (Table 5), and impact (Table 7) assessments to determine the relative importance of weeds by calculating a Pest Plant Score.

Pest Plant Score $=0.12 \times 0.788+0.32 \times 0.71+$ $0.56 \times 0.23=0.4506$

Table 7. Group and criteria ratings for determining impact of Acer negundo

\begin{tabular}{|c|c|c|}
\hline Criteria & Rating & Impact \\
\hline \multicolumn{3}{|l|}{ Social (tourism, visual aesthetics, experience, cultural sites) } \\
\hline 1. To what extent does the weed restrict human access? & 0 & 0 \\
\hline 2. To what level does this weed reduce the recreational use of the land? & 0 & 0 \\
\hline 3. To what level is the plant injurious, toxic, or spines affect people? & 0 & 0 \\
\hline 4. How much damage is done to indigenous or European cultural sites? & 0.25 & 0.003 \\
\hline \multicolumn{3}{|l|}{ Natural resources - soil, water \& processes } \\
\hline 5. To what extent does this weed impact on water flow within watercourses? & 0.5 & 0.0208 \\
\hline 6. To what extent does the weed impact on water quality? & 0.5 & 0.0417 \\
\hline 7. To what extent does the weed increase soil erosion? & 0 & 0 \\
\hline 8. To what extent does this weed reduce the biomass of the community? & 0 & 0 \\
\hline 9. To what extent does the weed change the frequency or intensity of fires? & 0 & 0 \\
\hline \multicolumn{3}{|l|}{ Fauna and flora / vegetation \& EVCs } \\
\hline \multicolumn{3}{|l|}{ 10. To what extent does this weed impact on the vegetation composition on the following: } \\
\hline a. High value EVCs & 0.75 & 0.0615 \\
\hline b. Medium value EVCs & 0.5 & 0.025 \\
\hline c. Low value EVCs & 0.25 & 0.0037 \\
\hline 11. To what extent does effect the structure of a vegetation community? & 0.5 & 0.0345 \\
\hline 12. What effect does the weed have on threatened flora spp.? & 0 & 0 \\
\hline \multicolumn{3}{|l|}{ Flora \& fauna/fauna } \\
\hline 13. What effect does the weed have on threatened fauna spp.? & 0 & 0. \\
\hline 14. What effect does the weed have on nonthreatened fauna spp.? & 0 & 0 \\
\hline 15. To what extent does this weed provide benefits or facilitates the establishment of indigenous fauna? & 0.75 & 0.017 \\
\hline 16. To what extent is toxic, its burrs or spines affect indigenous fauna? & 0 & 0 \\
\hline \multicolumn{3}{|l|}{ Flora and fauna/ fauna /pest animal } \\
\hline 17. Does this weed provide a food source to pest animals? & 0.25 & 0.0028 \\
\hline 18. To what extent does provide habitat / harbor for serious pests? & 1 & 0.017 \\
\hline \multicolumn{3}{|l|}{ Agriculture - quality, quantity, cost to production, effect on land value } \\
\hline 19. To what extent does this weed impact on the quantity of produce? & 0 & 0 \\
\hline 20. To what extent does the weed impact on agricultural quality? & 0 & 0 \\
\hline 21. To what extent does this weed affect land value? & 0 & 0 \\
\hline 22. To what extent does this weed change in priority of land use? & 0 & 0 \\
\hline 23. To what extent weed increases the cost of harvest? & 0.25 & 0.003 \\
\hline 24. To what extent does this weed act as a host for diseases of agriculture? & 0 & 0 \\
\hline
\end{tabular}


The obtained index of 0.4506 shows that $A$. negundo has a medium Pest Plant Score. However, this index is one of the highest compared with the results of previous studies on various alien tree species in Lithuanian forests, e.g., Quercus rubra - 0.3626 (Riepšas and Straigytė 2008) and Acer pseudoplatanus 0.3537 (Straigytė and Baliuckas 2012).

Rating may differ depending on habitant category, status of protected territories, historical places and etc. If invasive plants grow near protected territories, they can cause additional threats other than those in urban areas. In national parks, alien plants are generally undesirable. Rating priorities should be determined for separate regions taking into account the prevailing functions of the territories.

\section{Conclusion}

Acer negundo is the most distributed alien maple species in parks and greeneries in Riga and Kaunas and it has a very high invasiveness score. Dispersal is facilitated by movement along rivers. Their ability to survive spring flooding makes them successful competitors with other tree species. After cutting, they have the ability to regenerate from the stump, forming multi-stemmed trees. The obtained estimates indicated that box elder was spreading rapidly into new riparian habitats. Box elder has a low social, environmental and economic impact in the Riga and Kaunas, and does not have a large influence on agriculture: quality, quantity, cost to production, effect on land use and value currently. However the rapid dispersal of $A$. negundo could significantly influence flora, plant species composition and biological diversity in Riga and Kaunas in the future. In general, after evaluating all characteristics this species has a medium importance pest plant score.

\section{Acknowledgments}

The study was financially supported by the European Social Fund, the project No. 2013/0060/1DP/1.1.1.2.0/13/APIA/VIAA/041. The authors are thankful to dr. Dainis Rungis and Michael Manton for English correction.

\section{References}

Anonymous. 2004. List of invasive organism species in Lithuania. State Gazzete, 2004-08-21/No. D1433. (In Lithuanian)

Blouin G. 1992. Manitoba maple - an untapped resource. A preliminary report on the feasibility of developing a viable industry in the Canadian prairie provinces based upon the utilization of prod- ucts derived from the sap of Manitoba maple (Acer negundo L.). Forestry Canada, Northwest Region, Prince Albert, Saskatchewan. Canada-Saskatchewan Partnership Agreement in Forestry Miscellaneous Report.

Borisova E.A. 2011. Patterns of invasive plant species distribution in the upper Volga basin. Russian Journal of Biological Invasions 2: 1-5.

Cinovskis R., Janele I., Skujeniece I., Zvirgzds A. 1974. Trees and shrubs of Lativian Rural parks. Zinātne, Rīga. (In Latvian)

Cram W.H. 1983. Maturity and viability of boxelder maple seeds. Tree Planters' Notes 4: 36-37.

DeWine J.M., Cooper D.J. 2007. Effects of river regulation on riparian box elder (Acer negundo) forests in canyons of the Upper Colorado River Basin, USA. Wetlands 27: 278-289.

Erfmeier A., Böhnke M., Bruelheide H. 2011. Secondary invasion of Acer negundo: the role of phenotypic responses versus local adaptation. Biological Invasions 13: 1599-1614.

Friedman J.M., Auble G.T. 1999. Mortality of riparian box elder from sediment mobilization and extended inundation. Regulated Rivers: Research and Management 15: 463-476.

Gavrilova G.,. Šulcs V. 1999. Flora of Latvian vascular plants. Institute of Biology of University of Latvia, Laboratory of Botany, Rīgā. (In Latvian)

Green G.H. 1934. Trees of North America. Vol. 11. The broadleaves. Edwards Bros., Ann Arbor, MI.

Gudžinskas Z. 1998. Conspectus of alien plant species of Lithuania. 8. Aceraceae, Balsaminaceae, Elaeagnaceae, Geraniaceae, Hippocastanaceae, Linaceae, Lythraceae, Onagraceae, Oxalidaceae, Rutaceae, and Vitaceae. Botanica Lithuanica 4: 363-377.

Hobbs R.J., Huenneke L.F. 1992. Disturbance, diversity, and invasion: implications for conservation. Conservation Biology 6: 324-337.

Höfle R., Dullinger S., Essl F. 2014. Different factors affect the local distribution, persistence and spread of alien tree species in floodplain forests. Basic and Applied Ecology 15: 426-434.

Hosner J.F. 1960. Relative tolerance to complete inundation of fourteen bottomland tree species. Forest Science 6: 246-251.

Irving R.M. 1968. Study of dormancy, germination, and growth of seeds and buds of Acer negundo. Plant Physiology 43, Supplement, S49.

Janušauskaitė D., Straigytė L. 2011. Leaf litter decomposition differences between alien and native maple species. Baltic Forestry 17: 189-196.

Janušauskaitė-Lukaševičienè M. 1935. On acclimatization. Mūsu girios 8: 424. (In Lithuanian)

Kairiūkštis L. (ed.) 1968. Forests husbandry in the Lithuanian SSR. Vilnius. (In Lithuanian) 
Klinge J. 1883. Die Holzgewächse von Est-, Liv-, und Curland. Verlag von C. Mattisien, Dorpat.

Kolesnichenko M.V., Spakhov Y.M. 1969. Fiziol Rast 16: 1074.

Kowarik I. 1995. Time lags in biological invasions with regard to the success and failure of alien species. In: Plant Invasions: General Aspects and Special Problems. Pysek P., Prach K., Rejmanek M., Wade M. (eds.). SPB Academic Publishing, Amsterdam, the Netherlands, pp. 15-38.

Lietuvos TSR flora. 1971. IV: 619-620. (In Lithuanian)

Mędrzycki P. 2007. NOBANIS - Invasive Alien Species Fact Sheet - Acer negundo. In: Online Database of the North European and Baltic Network on Invasive Alien Species - NOBANIS www.nobanis.org.

Navasaitis A., Navasaitis M. 1979. Lithuanian trees. (In Lithuanian)

Navasaitis M. 2004. Dendrologija. Margi raštai, Vilnius. (In Lithuanian)

Olson D.F. Jr., Gabriel W.J. 1974. Acer L. In: Seeds of woody plants in the United States. Schopmeyer C.S. (ed.). Agriculture Handbook, U.S. Department of Agriculture, pp. 187-194.

Panetta F.D., Dodd J. 1987. Bioclimatic prediction of the potential distribution of skeleton weed (Chondrilla juncea L.) in Western Australia. Journal of the Australian Institute of Agricultural Science 53: 11-16.

Panetta F.D., Scanlan J.C. 1995. Human involvement in the spread of noxious weeds: what plants should be declared and when should control be enforced? Plant Protection Quarterly 10: 69-74.

Planty-Tabacchi A.M., Tabacchi E., Naiman R.J., Deferrari C., Décamps H. 1996. Invasibility of species-rich communities in riparian zones. Conservation Biology 10: 598-607.

Pūka T., Cinovskis R., Bice M., Ievina S. 1988. Rīgas sabiedriskie apstādījumi. Zinātne, Rīga. (In Latvian)

Ramanauskas V. 1973. Dendrologija. Mintis, Vilnius. (In Lithuanian)

Rauktys J. 1933. Trees, shrubs and subshrubs useful for ornamental purposes. Mūsų girios 4: 273-276. (In Lithuanian)

Reichard S.H. 1994. Assessing the Potential of Invasiveness in Woody Plants Introduced in North America. University of Washington Dissertation, Seattle, WA.

Reinhart K.O., Callaway R.M. 2004. Soil biota facilitate exotic Acer invasions in Europe and North America. Ecological Applications 14: 1737-1745.

Rejmánek M., Richardson D.M. 1996. What attributes make some plant species more invasive? Ecology 77: 1655-1661.
Riepšas E., Straigytė L. 2008. Invasiveness and ecological effects of Red Oak (Quercus rubra L.) in Lithuanian forests. Baltic Forestry 14: 122-130.

Roe E.I. 1941. Effect of temperature on seed germination. Journal of Forestry 39: 413-414.

Saaty T.L. 1995. Decision Making for Leaders: The Analytical Hierarchy Process for Decisions in a Complex World. RWS Publications, Pittsburgh.

Schopmeyer C.S. 1974. Seeds of woody plants in the United States. U.S. Department of Agriculture, Agriculture Handbook 450. Washington, DC.

Skridaila A. 2001. Introduction of woody plants in Vilnius University Botanical Garden in 17812000. PhD thesis.

Straigytė L., Baliuckas V. 2015. Spread intensity and invasiveness of sycamore maple (Acer pseudoplatanus L.) in Lithuanian forests. iForest: doi: 10.3832/ifor0763-007.

Stravinskienè V. 2010. Monitoring and assessment of tree health condition in Kaunas city environment. Journal of Environmental Engineering and Landscape Management 18: 217-225.

USDA, NRCS, PLANTS Database, plants.usda.gov. National Plant Data Center, Baton Rouge, LA 70874-4490 USA.

Valantinaitė A., Straigytė L., Jurkšienė G. 2011. Comparative analysis of invasion intensity of box elder (Acer negundo L.) and sosnowskyi hogweed (Heracleum sosnowskyj Manden). Rural Development 2011, Proceedings 2: 161-166.

Victorian Pest Plant Prioritisation Process: methodology. 2002.

http://www.dpi.vic.gov.au/dpi/vro/vrosite.nsf/ pages/invasiveness criteria.

Wagner C.H. 1822. Preis-Courant derjenigen Gemüse-, Blumen-, Bäume- und SträucherSamen welche frisch und gut beigesetzte Preis zu haben sind bei Carl Heinrich Wagner. Riga.

Weiss J., McLaren D. 2002. Victoria's Pest Plant Prioritisation Process. In: Proceedings of the 13th Australian Weeds Conference. Spafford H.J., Dodd J., Moore J.H. (eds.), pp. 509-512.

Williamson M., Fitter A. 1996. The Varying Success of Invaders. Ecology 77: 1661-1666.

Wilson R.E. 1970. Succession in stands of Populus deltoides along the Missouri River in Southeastern South Dakota. American Midland Naturalist 83: 330-342.

Zarinšs L. 1959. Maple species distribution and pertinence to local conditions in Latvia SSR. In: Daildārzniecība. Augu introdukcija un zalā celtniecība Latvijas PSR. Kalniņš A. (ed.). Latvijas PSR ZA izdevniecība, Rīga, pp. 119-134. (In Latvian)

Zigra J.H. 1817. Ausführliches Verzeichniss derjenigen Pflanzen, Bäume und Sträucher, welche in 
Riga in der Garten von J.H. Zigra gezogen werden. Gedruckt bei J.E.D. Müller, Riga.

Žalkauskas R. 2000. Spread of wooden plants on banks of Kaunas sea and their influence on capes shaping. Miškininkystė 45-46: 12-24. (In Lithuanian). 